\title{
Colin James
}
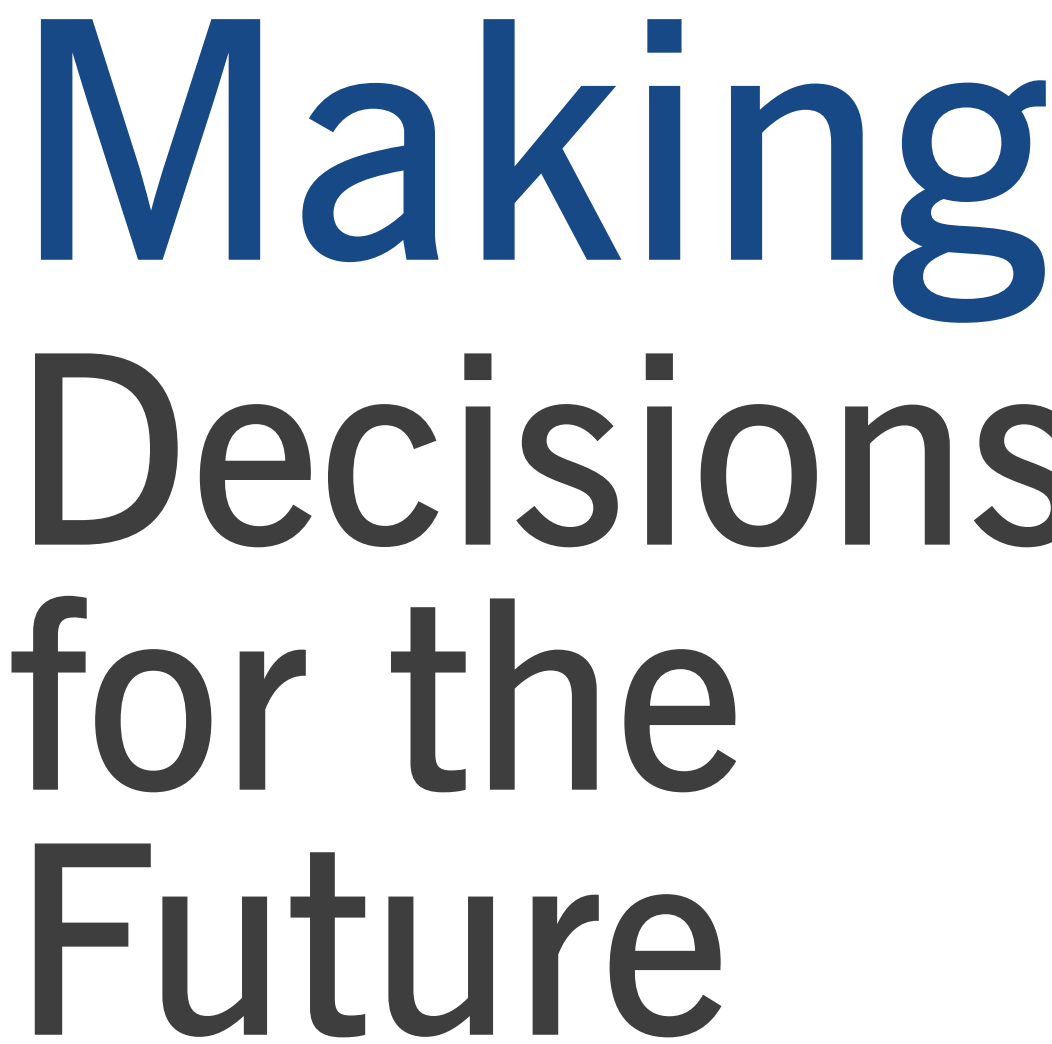

The Treasury's long-term fiscal projections are designed to inform present-day policy. They draw attention to existing trends and potential future global and national developments in society, demography, politics, technology and the economy, and the fiscal implications of continuing existing policy unchanged through those changes over the next 40 years and beyond. They highlight that the later action is

Colin James is a political columnist and analyst. In 2012-2013 he was a member of the Treasury/ Victoria University of Wellington Long-Term Fiscal External Panel. This article is a cut-down version of a paper he presented at the Treasury/Victoria University of Wellington Affording Our Future conference in December 2012. The full paper is available at www.colinjames.co.nz and also at http://www. treasury.govt.nz/government/longterm/fiscalposition/2013. The author would like to thank Jess Booker for assisting with the research for this article.

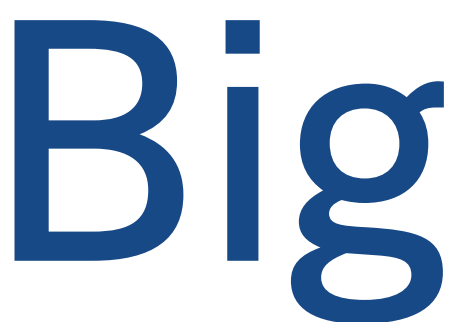

taken to offset an anticipated impact, the greater the policy change may have to be and also potentially the cost, not just in money but also in social cohesion if unusual intergenerational tensions develop as a consequence. But if large adjustments have to be made, even if over time, how might that be done in a representative democracy in which the ultimate decisionmakers, the politicians, are subject to frequent elections in which political folklore tells us the determinant issues are proximate and 'courageous' leaders are sacrificed to short-term voter self-interest? 
In fact, major policy changes have been made here and in other countries of our sort in which voters have submerged their individual interests in the national interest or in the interests of overall economic performance or social cohesion, or for altruistic, ethical or moral motives. To be successful and durable a policy change must be underpinned by consensus, or at least broad public acquiescence amounting to consensus by default. Thus, any policy settings, including fiscal policy settings, must be resilient: that is, have a strong core which endures through shocks and a surrounding flexibility which enables
There are continuities and trends, such as the changing nature of the 'family' and the constitution of households, the role of women, and the nature of education in response to the changing nature of 'work'. Unless there is high inward migration similar to that which occurred after 1840, or there is a highly destructive pandemic or other disaster (both possible), the proportion of older people will likely rise. The geopolitical and geo-economic rebalancing of the past 30 years following the marketisation of the Chinese economy is likely to continue, with changes of direction and speed, and that rebalancing

\section{A Māori in 1813 could not have predicted the disjunctive Treaty of Waitangi, and any New Zealander in 1973 might have imagined but not predicted the resurrection of the Treaty of Waitangi and the invention of biculturalism.}

shocks to be absorbed, responded to and transcended or survived, and enables adaptation to changing conditions.

A 40-year projection is also by definition multigenerational (transgenerational and intergenerational). Making multigenerational policy is not straightforward. In a democracy, future generations - those not yet born and those still children - do not vote, except to the extent that living generations take them into account and vote on their behalf (a sort of 'virtual' vote). Past generations - those who have died - also do not vote, except to the extent that tradition influences the votes of living generations (another 'virtual' vote). Among the living and voting generations there are different and competing values and priorities, and thus expectations and hopes of, and needs from, fiscal settings, which in a representative democracy shape and constrain politicians' decisions on policy and can overweight the present at the expense of the future and generate perceptions of intergenerational inequity. ${ }^{1}$ Some see this as a breakdown of an implied social contract or partnership. ${ }^{2}$ will set fiscal and other economic and social parameters.

\section{Disjunctive and transformative events}

But long-range projections must also assume the possibility, even probability, of another shock of the size and impact of the global financial crisis, after which the global and local social, economic and political landscape is qualitatively different. The history of the past century or so suggests that in the next 50 years there will be another such disjunctive event. In addition, one or more transformative events are likely, which will also affect the context for policy. These events are unforeseen and unpredicted, though historians in retrospect habitually discern observable forces and pressures preceding a disjunctive event and a transformative event may be theorised, imagined or fantasised in advance.

A disjunctive event suddenly accelerates social, political and economic change, rather as an earthquake suddenly repositions tectonic plates after a long build-up of pressure and reshapes the surface landscape; or irrupts from outside, much as a tsunami does; or results from a sudden breakdown of order in the complex system that is human society. Afterwards, the social and economic landscape looks different, often very different, and while much of what is on the landscape looks familiar, it, too, is often deeply changed.

The standout example in the past 100 years was the First World War, which far exceeded contemporaries' expectations and resulted in the destruction of four empires, the serious weakening of a fifth, the killing of about 10 million soldiers, and the transformation of war, the rise of communism and fascism and a second destructive world war. A second example was the 1929 financial crash which caused worldwide economic depression (contributing to the rise of fascism), drove governments to actively manage their economies and reduce social disparities with far-reaching tax, education, health, housing and income support policies, and led to the creation of the Bretton Woods system of fixed-exchange rates, the International Monetary Fund and the General Agreement on Tariffs and Trade to guard against a repetition. Others are the 1973 oil price crisis, which ended the Bretton Woods regime, the collapse of communism in 1989, which radically changed the world order, and the recent global financial crisis.

Why do these occur? Historian Niall Ferguson, among others, has argued that human society is a complex system, akin to a biological system. Such systems, he argues, are 'made up of a very large number of interacting components that are asymmetrically organised' and 'operate somewhere between order and disorder - on the edge of chaos'; they seem to be in equilibrium until 'there comes a moment when they "go critical" ... a very small trigger can set off a "phase transition" from a benign equilibrium to a crisis' (Ferguson, 2012, p.22). ${ }^{3}$

A transformative event is a scientific discovery or technological, political, business, organisational or way-ofthinking innovation. It changes the quality of life or the way people live or see the world around them, often for better but sometimes for worse. Positive transformative events are the work of 
what United States economist Richard Florida has called the creative class (Florida, 2002, 2007). They can contribute to or trigger disjunctive events.

Transformative events in the 40 years after 1913 included the discovery of penicillin and DNA's double helix; the splitting of the atom; the invention of the transistor and the computer; and a fashion event, the bikini (a symbolic indicator of deep changes in mores to come). ${ }^{4}$ All had profound, unpredicted and unpredictable effects on economic and social life. Digital technology - the transistor-computer-internet-newmediarobotics-3D evolution - may only now in this decade be beginning to realise its true transformative influence on economic, social and political/security trajectories.

A New Zealand forecaster in 1913 would have been star-gazing or daydreaming to predict within 40 years aerial topdressing, social security and a national state health system, and 14 years of a Labour government, all transformative. A Māori in 1813 could not have predicted the disjunctive Treaty of Waitangi, and any New Zealander in 1973 might have imagined but not predicted the resurrection of the Treaty of Waitangi and the invention of biculturalism.

The point for policy makers is that, while there are trends in the evolution of societies, political systems and economies, there are also occasional events which distort, divert, accelerate or stall those trends or open new and out-of-the-ordinary possibilities. Such events in the next 40 years might be generated by the likes of climate change, water shortages, turmoil in the Middle East, a virulent pandemic, a new twist in hyper-globalisation, upsets in China and elsewhere in Asia, the collapse of multilateral rules-based systems such as the World Trade Organisation, new medical technologies and practices, new production methods, a radical generational shift, and New Zealand becoming a highly desirable place to live.

That might suggest focusing on the predictable short term and not trying to plan for or make allowance for more distant events that might or might not happen. Actually, the whiplash in the fiscal parameters in 2008-09 suggests otherwise, as do the Canterbury earthquakes. Anticipating that there are outlier possibilities enables contingency planning, which in turns improves resilience in the face of the unpredicted. Over recent decades it has become more common for firms and some government agencies to scan the possibility of major disruptive - disjunctive or transformative - events and to have thought about it, so that if one happens at least some contingency planning has been done. ${ }^{5}$

At the same time, wise firms and governments also work out what they most expect to happen over three, five, types of policies can be applied to prepare for and manage through uncertainties: 'no-regrets initiatives', 'hedges against key risks', 'boundary or handrail issues' and 'core bets' (Baker et al., 2012).

The BCG paper is not the first or last word. But it illustrates the decisionmaking context for long-term fiscal projections: to prepare for the most likely eventuality well before it happens, and also to keep in mind the possibility of shocks and think about how to manage them if they occur.

The usual default position, by contrast, is to take no action until forced

\section{... an OECD study of major decisions on pensions and health services ... found that those made in response to a crisis, while easier to promote at the time, are likely to endure only if there are quick pay-offs ...}

ten or 20 years. They can then take early action to counter adversity or take advantage of opportunity. Government in essence is about risk management and the risks to be managed are distant and proximate, known and unknown, natural and societal.

\section{Risk management and anticipatory policy} change

One way of looking at this is suggested in a recent paper by the Boston Consulting Group (BCG). The paper argued that: 'Governments have become flexible about what they should do but rigid about how to do it. Good strategy in government involves doing the opposite: being clear about goals but flexible about how to deliver them.' Societies, BCG argued, 'are identical neither to machines, which can be engineered'-byinference the presumption that underlay the interventionist, planned welfare state - 'nor to biological systems, which evolve by themselves. Instead, they combine aspects of both and hence need a mixture of direction and adaptation'. BCG instanced foresight and scenario planning techniques, which 'can't predict the future but can prepare you for it'; then different to by a crisis. But an OECD study of major decisions on pensions and health services (detailed in James, 2012, pp.1920) found that those made in response to a crisis, while easier to promote at the time, are likely to endure only if there are quick pay-offs (OECD, 2010). The OECD warned that while a crisis opens a window of opportunity, ${ }^{6}$ that might as a result come when there is less financial scope to meet upfront costs to ensure reforms work, can obscure long-term needs and objectives and can lead to capture by some agencies.

That suggests durable major reforms reflect some combination of deeper currents-demographic, economic, social, psycho-sociological, intellectual, politicalsociological, or external (geo-economic, geopolitical or bilateral-national). That was so in major policy changes in Britain through the 19th century and New Zealand in the 1890s, 1930 s and 1980s (detailed in James, 2012, pp.11-18). There were a number of drivers, with a different mix in each case: deep change in the demographic or class structure of society and/or in the economy or commercial practice; social distress and humanitarian 
concerns, including as a result of economic depression; fear of disorder if no action is taken and/or reaction to disorder; a major shift in the prevailing intellectual wisdoms or fashions, picked up by and advocated by political parties and/or officials; courage, leadership or political will and/or strategic thinking and/or visionary ambition exhibited by leading public figures; interest group pressure, especially if there is a change in the balance of interest groups; fiscal pressure; and momentum once action was initiated.

The OECD study also suggests that for major reform to be durable it must either give effect to, anticipate or build consensus, or at least majority support. Most policy change is incremental, and either builds consensus or a majority progressively with each increment, positive endorsement (see further James, 2012, pp.22-4).

Climate change is not the only issue which poses the question of whether policy should be anticipatory. Others include (and this is only an indicative list): resource sustainability here and abroad, especially of water (and so food production) and minerals; the impact of new forms of economic globalisation on the distribution of work; the impact of $3 \mathrm{D}$ printing and other new forms of production technology for goods and services; the geopolitical and security implications of the rise of China; and the implications of gene technology, among other emerging forms of treatment of illness, disability and physical inequalities. All have the potential to profoundly alter the fiscal trajectory over the next 40 years.

\section{Increasingly, the public ... expects to participate at some times in decisions on some things in some way or to some degree, or expects at least to be listened to or acknowledged.}

or gives effect to an already existing consensus or majority. Major policy reform will endure if it evokes or reflects a pre-existing latent consensus, as for social security in the 1930s. But if the reform is unexpected or unforeshadowed - that is, a shock - or is in anticipation of events not yet experienced by or evident to the majority (as with climate change), the reform will endure only if consensus can be constructed as the reforms are done or shortly afterwards. Consensus was slow to develop after New Zealand's radical 1984-92 deregulatory reforms: the vote for MMP was essentially a vote against both the Labour and National parties for departing from their social democratic and moderate conservative roots respectively. A quasi-consensus did eventually develop, but it was by way of gradual acquiescence to the new policy settings because Labour and National offered no alternative, rather than
Particularly pertinent to that fiscal trajectory is the 'ageing' of the population - a higher proportion of older people dependent on a smaller proportion of 'working-age' people. The presumption is that health costs and income support (superannuation) for this larger 'aged' group will rise to the point that they are too onerous for those who will be of 'working age'.

The policy argument for anticipatory policy change is that it is less onerous to take early action than to change policy only when the costs begin to mount, and that policy change made deliberately and over time is also more likely to be durable than policy made under fiscal pressure or in crisis. The policy argument against anticipatory policy change is that action may not be necessary because circumstances might change and there is an opportunity cost in taking needless action. Will population projections turn out to be accurate, or too low or high? Will the fact of more older people add to health care costs, or might near-endof-life health costs fall because babyboomers have lived a better-fed, healthier and less physically wearing childhood and working-age life and will be healthier for longer, and thus physicians may intervene less vigorously near end of life? Will new technology go on driving up health care options and costs, or might technology, coupled with workforce organisational change and price-reducing innovation in 'emerging' countries, reduce health care costs in net terms and reverse the current net-positive effect? Will 70 be the new 65 and so will more people continue in paid work, thereby lowering pension costs, or might rising capital accumulation costs increase pension costs?

These sorts of questions, unanswerable in advance, underline that any longterm fiscal path chosen or foreshadowed raises issues of transgenerational and intergenerational equity and sustainability: transgenerational as between the generations at any point in the 40 years, and intergenerational as between a particular generation's experience a generation hence and their corresponding age cohort now.

Today's cohort of politicians is trapped in short-term electoral cycles, and their officials are bound to carry out their lawful decisions. In that sense officials are 'state' servants. But those same officials are also 'public' servants, bound to keep in mind, to develop and redevelop and to promote a long and broad view on behalf of the public.

\section{Participation and leadership}

This dimension of officials' brief highlights that in a modern liberal democracy parliamentary representation is not sufficient. Increasingly, the public (more accurately some of the public) expects to participate at some times in decisions on some things in some way or to some degree, or expects at least to be listened to or acknowledged. Increasingly, mechanisms are being constructed, tested and used to develop, refine and validate policy change. Without that validation, policy change may not be durable (King et al., 1998). 
This doesn't diminish the importance of leadership. Any durable major policy change, including anticipatory change, requires leadership, either by political leaders or as a result of their responding to leadership from outside the formal political system through one of a number of mechanisms. The most promising of these mechanisms entail some public involvement. Politicians themselves have generated it through opening up access to information (via the Official Information Act), making Cabinet papers public and consulting on proposed policy in a variety of ways, including discussion papers, parliamentary select committee hearings, meetings with the iwi leaders forum, and advisory and working groups (tax, welfare).

This growing expectation is not a linear growth. People get involved sporadically, issue by issue, and many still never get involved. But there does appear to be a trajectory. This suggests that leaving long-term fiscal matters to officials and politicians (though politicians do the final sign-off of any policy) will not generate the underpinning consensus needed to address those matters durably and to enable adjustments through time.

\section{Extra-parliamentary mechanisms for reform}

There is a wide range of extraparliamentary mechanisms, ranging from populist through experimental to prototype.

One experiment initiated by ministers was the Land and Water Forum to develop the basis for water policy through 'collaborative governance'. In 2009 this brought together all 58 organisations with an interest in allocation and management of water and mandated them to reach consensus on the foundations of policy. That took three and a half years and the government is now broadly implementing its report. Labour and the Greens have backed it, too. Its virtue was the broad buy-in by all interest groups, including by iwi, so iwi cultural, economic and other perspectives and needs were explicitly incorporated.

But collaborative governance of this sort does not involve the general public, whose views are not wholly expressed through interest groups any more

accurately or completely than through political parties. Nor are all Māori represented by iwi leaders, who in any case have direct access outside the forum (and any other channel) to negotiate with senior ministers as the 'Treaty (of Waitangi) partner'.

An alternative is a binding referendum. Switzerland has the most developed referendum system, deciding a wide range of matters at federal, canton and local level that way, with extensive programmes to inform the public on each issue (though this can hold up progress, as in the fact that women did not get the vote in all elections until 1990). In many states in the United States there are binding citizens-initiated referendums (known as propositions), some of which have had unintended consequences. Here, citizens-

\section{Public opinion polls and focus groups are extensively used by political parties and interest groups [but] ... there is a wide variety of other formal and semi-formal mechanisms.}

initiated referendums are non-binding, and no government has yet acted on one, as the current government has signalled will be the case if the referendum on asset sales goes against sales. Otherwise, referendums are still rare, though it is now close to a constitutional convention that major constitutional or electoral change must be decided by referendum.

Critics say complex issues cannot be reduced to the simple form in which a referendum question must be stated, and that it is impossible, or at least impracticable, to sufficiently educate the general public to elicit an informed decision. The complexity of issues involved in long-term fiscal projections suggest that the necessary decisions would not fit a referendum format.

An alternative is a national convention, as used to draft the original United States constitution, and, in February 1998, in Australia to draft a referendum on whether Australia should abolish the monarchy in favour of a republic. But a national convention tends to be of the 'great and the good'.

A parliamentary petition can involve the wider public, if many sign. This still leaves the decision in the hands of the politicians, but can at times force their hand, as in 1970 over the proposal to raise Lake Manapouri as part of a hydroelectricity project. Public opinion polls and focus groups are extensively used by political parties and interest groups to gauge public opinion, and, within limits, mould it. But polls are in effect referendums without responsibility and usually based on limited knowledge. Moreover, it is becoming increasingly difficult to assemble a fully random sample of voters. A focus group is a sort of 'jury': an issue is discussed for one or two hours, with information progressively inserted into the discussion so that over time the group comes to a more considered opinion than is possible in a poll. But focus groups are not representative.

There is a wide variety of other formal and semi-formal mechanisms. ${ }^{9}$ One survey lists citizens juries, planning cells, deliberative polling, consensus conferences and citizens panels (Abelson et al., 2003). Another lists focus groups, citizens juries, consensus conferences, cooperative discourse, dialogue groups, stakeholder workshops, participatory expert workshops, reflection forums, deliberative interviews, voluntary agreements, eco-audits, policy simulation exercises, deliberative foresights, concerted environmental management, mediation, regulatory negotiation, consultative forums, deliberative conflict resolution processes and environmental negotiations (Van den Hove, 2006). 


\section{'Deliberative' and 'participatory' reform}

In those lists there are two important words. One is 'deliberative'. One commentator argues that ' $\mathrm{t}$ ] he essence of democracy is now widely taken to be deliberation, as opposed to voting, interest aggregation, constitutional rights or even selfgovernment' (Dryzek, 2000, p.1, as quoted in Abelson et al., 2003). This involves, according to another, 'a particular sort of discussion - one that involves the careful and serious weighing of reasons for and against some proposition' (Fearon, 1998, p.1, as quoted in Abelson et al., 2003). on a national issue. Again, they are not used to make decisions, but they do present much more considered positions on significant topics: for example, in Britain on crime, the monarchy, the future of Europe and the health service. A Japanese deliberative poll involving 127 people (from a random nationwide sample of 3000) at Keio University on 2829 May 2011 on the topic 'Pension system, a generational choice' first met in small groups with experts, then in a plenary, totalling ten hours of deliberation. Among the conclusions were that the

\section{... electoral systems, while complex, are not as complex as fiscal issues, especially long-term fiscal issues.}

The other important word is 'participatory'. Citizens juries and planning cells have been used in the United States and Germany respectively to examine an issue and present a conclusion to the media, interested groups or a sponsor. Variations have been tried in emerging-economy countries and developing-economy countries. But a criticism is that the juries do not parallel actual courtroom juries: they involve only the jurors and witnesses and do not feature lawyers contesting evidence or judges.

Consensus conferences in Denmark inquire into scientific or technical issues and have been used to develop clinical guidelines. The goal is 'not to reach a kind of objective scientific truth but to feed into the political channels and clarify public opinion'. They have been running for 20 years, 'have received due political recognition ... are closely followed by the media, there is always a great attendance of public and a lively public discussion about the issue and the recommendations of the panel afterwards' (Zurita, 2006, p.21). But note that they are used for tightly defined issues, not large, multidecadal issues.

Deliberative polling assembles a large, representative, random sample who deliberate over two to three days, usually consumption tax should be increased and used for social security' and 'we should take future generations into account more than the current generation' (Nemoti, 2011). Support for both of those propositions was greater when participants were asked after deliberation than before. A Victoria University survey of attitudes to climate change-driven sealevel rise found that different responses were elicited according to whether any information was given, and, if so, whether a reference year of 2050 or 2100 was used and whether projections were moderate or extreme, 'though effects were usually small': 'People were generally more concerned and more supportive when they received information' (Evans et al., 2012, p.3). ${ }^{10}$

A more ambitious version of citizen deliberation is the citizens assembly. Citizens assemblies have been used in British Columbia and Ontario in Canada (mandated by the provincial parliaments) and in Holland (mandated by the government) to come up with recommendations on electoral reform. ${ }^{11}$ The British Columbia assembly followed the most exhaustive process of the three, over 11 months: near-random selection of 160 people, one male and one female from each riding; a learning phase over six weekends, involving experts and wide reading, which resulted in 'these ordinary citizens' acquiring 'an extensive knowledge and understanding of electoral systems'; a consultative phase during which members went out to public hearings in 50 meetings, some attended by politicians, coupled with a website which received written submissions and proposals; then deliberation. The process culminated in a recommendation to the parliament, which put the question to a referendum which was narrowly defeated (it required $60 \%$ to pass and the vote was $57.7 \%)$. Polling found members of the public trusted the assembly as being more like themselves than politicians (though indigenous and ethnic minorities were heavily under-represented). The other two assemblies also resulted in no change, for other reasons (Hayward).

How useful could these mechanisms be in reaching decisions on major policy change, especially anticipatory policy change? One assessment of the British Columbia assembly found that 'citizen political decision-making appeared to be of a remarkably high quality' (Vander Ploeg, 2003, p.222, as quoted in Hayward) and showed that citizens 'have the capacity to shed their apathy, overcome their ignorance and reason conscientiously about an unfamiliar and complex political issue' (Warren and Pearse, 2008, p.6, as quoted in Hayward). After all, politicians are amateurs, too.

But assemblies have not yet been widely tested on national issues, and all three on electoral systems did not result in change. Moreover, electoral systems, while complex, are not as complex as fiscal issues, especially long-term fiscal issues. Hence one observer's assessment that, 'While in theory deliberative processes could be designed to guarantee binding decisions, in reality the stakes are often too high to delegate this authority to a group of citizens and the public may not care to assume this level of decisionmaking authority' (Abelson et al., 2003, p.247). If they were to be effective on long-term fiscal issues, they would need development.

Where this approach does seem to get closer to decision-making is at the local level. Citizen commissions are widely used in Switzerland to resolve differences 
over such matters as where to site a waste disposal plant or infrastructure projects (Anonymous, 2012). A New Zealand example that attracted international academic attention was a planning project in Wanaka in 2002 to develop a plan for 2020 (Bond and ThompsonFawcett, 2007).

Nevertheless, even if a citizens assembly (or jury) is not yet a proven vehicle for decision-making at national level, could it be useful in shaping public opinion? If the media were to take an interest, that might generate wider public interest, and if the assembly was seen to be representative and not beholden to any political party or interest group, its deliberation and recommendations might get traction. At the least, an assembly could open a channel for better communication of, and better education about, policy issues and decisions, at the same time requiring more rigorous explanation to citizens.

An assembly is probably not enough on its own and would need reinforcing. There is a risk that it could be misused by politicians and officials to co-opt or persuade (Roberts, 1997). ${ }^{12}$ It can be costly, may not actually engage citizens beyond those directly involved, and may not be any more representative (and perhaps be less representative) than politicians, since the vocations of those involved don't depend on the outcome and might (as with politicians) produce a result reflecting the preoccupations or emotions of those who get involved. One checklist of settings for effective and efficient citizen participation is: 'careful selection of a representative group of stakeholders; a transparent decisionmaking process to build trust among the participants; clear authority in decisionmaking; competent and unbiased group facilitators; regular meetings; and adequate financial resources' (Maitlis and Ozcelik, 2004, p.390).

\section{Addressing the policy tensions}

If a citizens assembly did address longterm fiscal issues, it would have to wrestle with three major tensions. One is the balance between PAYGO (paying for government services out of current tax revenue and borrowing) and SAYGO (the government and/or individuals saving and accumulating funds to address current and future service expectations and liabilities). New Zealand has for many decades favoured PAYGO, though the New Zealand Superannuation Fund, KiwiSaver and the Accident Compensation Corporation's future liability funding are public examples of SAYGO.

Related to that is intragenerational equity. The balance between funding services from taxes and from private funding has obvious implications for the spread of income and wealth and so personal well-being (that is, for levels. That will require New Zealand to recalibrate its assessment of the optimal, desirable and possible levels of taxation and state spending against a different, and less generous, set of comparator countries (see, among others, Tanzi, 2005 and 2011, and McRae, 2011 (reviewing Tanzi, 2011)). ${ }^{13}$

In a democracy these questions are resolved, one way or another, by the people, usually through the crude mechanism of elections, the rise and fall of political parties and their ideologies, the interplay of interest groups, pressure groups and politicians, and, occasionally,

\section{Of all the mechanisms canvassed ..., the most promising would be either a national convention or a citizens assembly: a transparently representative citizens assembly would be more appropriate because more democratic.}

(inequality'), and therefore for social cohesion at any given time and potentially, if not addressed, over time. Tied up with this is intergenerational equity, the equity between generations at any one time.

Related to that is transgenerational equity, fairness of contribution and access to services as generations age and new generations arise. Is it right to have sudden shifts between SAYGO and PAYGO or in intragenerational equity, or should any necessary changes be smoothed over time? A liberal-Enlightenment approach based on the primacy of individual liberty and sanctity might argue that it is, that generations and cohorts are separate and costs should lie where they fall. A conservative, Burkean notion of 'contract' or 'partnership', binding generations to each other, might take the opposite view.

Deciding these matters will be in a context in which the countries with which we trade and compete will increasingly be those which have far less developed social support systems and which, as they do build those systems to offset unsustainable inequalities, are unlikely to expand them to 'western' economies' peak mass public action. When affairs are going smoothly these adjustments go fairly smoothly too. But in crisis, or (as now) after a disjunctive shock or facing looming major geopolitical, geo-economic or national changes, some predictable, some unknowable, there is arguably value in developing the means to discover and develop public consensus and, with that, resilience. Given New Zealand's past capacity for inventive policy, in three periods of major change and in a range of policy innovations between those periods, there is no compelling reason why it cannot develop the model for 21stcentury democracy.

Of all the mechanisms canvassed above, the most promising would be either a national convention or a citizens assembly: a transparently representative citizens assembly would be more appropriate because more democratic. Even though fiscal matters, being very complex, may be thought beyond the capability of 'ordinary' citizens, analysis suggests that there is no compelling reason why a well-constituted assembly could not gain a good understanding of the 
issues and produce a sensible, politically saleable and sustainable outcome.

But there would be no point to calling a citizens assembly unless it was of high quality in its selection, the commitment of its members, the information it was given and the way that information is debated, and its connection with the wider citizenry. Political parties would need to commit to taking its findings seriously. Logically, such an assembly would also not be a singular event but repeated every ten years or so. By the end of 40 years, if the process worked well, it would likely become a workable fixture.

That is a very tall order. It would amount, in short, to setting an international standard, a big challenge to politicians' and officials' capacity for leadership. 1 Bull (2012) presents an interesting discussion of this point in
the context of climate change.

2 For example, Ferguson (2012, p.43) quotes Edmund Burke: one of the first and most leading principles on which the commonwealth and the laws are consecrated is, lest the temporary possessors and life-renters in it, unmindful of what they have received from their ancestors or of what is due to their posterity, should act as if they were the entire masters, that they should not think it among their rights to cut off the entail or commit waste on the inheritance by destroying at their pleasure the whole original fabric of their society, hazarding to leave to those who come after them a ruin instead of an habitation - and teaching these successors as little to respect their contrivances as they had themselves as little to respect their contrivances as they had themsel
respected the institutions of their forefathers ... Society is indeed a contract ... the state ... is ... a partnership not only between those who are living but between those who are living, those who are dead and those who are to be born.' Ferguson applied the quote to 'the enormous intergenerational transfers implied by current fiscal policies', which he saw as 'a shocking and perhaps unparalleled which he saw as 'a shocking and pe
breach of precisely that partnership'.

3 Ferguson continues (p.25): 'The political and economic structures made by humans share many of the features of complex adaptive systems ... Whether the canopy of a rain forest or the trading floor of Wall Street, complex systems share certain characteristics. A small input to such a system can produce huge, often unanticipated changes - what can produce huge, often unanticipated changes - what
scientists call the amplifier effect ... Causal relationships scientists call the amplifier effect ... Causal relationships
are often nonlinear, which means that traditional methods of generalising through observation (such as trend analysis and sampling) are of little use. Some theorists of complexity ... say that complex systems are wholly non-deterministic, meaning that it is impossible to make predictions about their future behaviour based on existing data. When things go wrong in a complex system the scale of disruption is nearly wrong in a complex syste
impossible to anticipate.'

4 If we look out 47 years from 1913 to 1960 (the span from 2013 to 2060), there were also the launching of the first space satellite in 1957 and the contraceptive pill (approved for use in 1960).

5 In an environmental scan looking out ten years I did with Statistics New Zealand through the second half of 2006 I rated as a $25 \%$ probability: 'Imbalances unwind messily; recession or sharp slowdown in US triggers world recession', and as a possible 'shock' 'a full-scale world recession, triggered by terrorism, a messy unwinding of the imbalances or natural/medical disasters'. Other possible shocks included 'The Middle East explodes/implodes and/or revolution in Saudi Arabia', and 'Major earthquake devastates Wellington'; both had some relation to recent actual events. So, too, did another 25\% probability: 'Significant earthquake in less populated area'.

6 Roger Douglas as finance minister used to talk explicitly of the window of opportunity, a financial squeeze opened for the 1980s policy changes which he spearheaded. In the wake of the 1987 stockmarket crash he thought he had another window of opportunity, this time for a flat tax, but Prime Minister David Lange, backed by a (silent) majority in the Labour caucus, shut the window.

7 This may be a partial explanation for declining election turnouts over the past 50 years (though there is no hard research evidence that this is so). Voting is more a delegation of authority than a form of participation.

8 This distinguishes a national convention from an unofficial gathering called a 'convention' (such as the women's convention in New Zealand in the 1970s).

9 Valentina Dinica of the School of Government, Victoria University of Wellington, assisted with some pointers in this section of the original paper.

10 Evans et al. (p.3) go on to note that 'When focused on extreme projections, people anticipated greater sea level rise, felt that sea-level rise was a more serious problem for them personally, and showed greater support for adapting to climate change and for individual adaptation options, such as accommodation and retreat. They also perceived sea-level rise as a nearer-term threat when information was framed to focus on 2050 and the more extreme projections. Importantly, more "extreme" information always resulted in more concern and support from respondents.'

11 The British government used what it billed as a citizens assembly to build initial support for raising the superannuation age. But informal comments to me from a participant indicate it was managed by the government and so does not warrant description as a citizens assembly in the sense it is used in this article - certainly not on the British sense it is used in this article - certainly not on the Britis
Columbia model, where politicians kept at arm's length except in some of the public hearings.

12 This could be said of the British example cited above.

13 Tanzi has argued an optimal taxation level of $35 \%$ of GDP. This compares with around $25 \%$ in New Zealand in 1973, a difference which raises questions about the value of setting a precise number on taxation.

\section{References}

Abelson, J., P.-G. Forest, J. Eyles, P. Smith, E. Martin and F. Gauvin (2003) 'Deliberations about deliberative methods: issues in the design and evaluation of public participation processes', Social Science and Medicine, 57 (2), pp.239-51

Anonymous (2012) 'Let's Make a Deal', Pictures of the Future, Spring 2012, pp.50-3

Baker, C., J. Purnell and M. Reeves (2012) Adaptive Strategy in Government, Boston Consulting Group

Bond, S. and M. Thompson-Fawcett (2007) 'Public participation and new urbanism: a conflicting agenda?', Planning Theory and Practice, 8 (4), pp.456-9

Bull, M. (2012) 'What is the rational response?', London Review of Books, 34 (10), pp.3-6

Dryzek, J.S. (2000) Deliberative Democracy and Beyond, Oxford: Oxford University Press

Evans, L., T.L. Milfont and J. Lawrence (2012) Perceptions of sea-level rise in Wellington City and Kapiti Coast districts, Wellington: Victoria University of Wellington

Fearon, J.D. (1998) 'Deliberation as discussion', in J. Elster (ed.), Deliberative Democracy, Cambridge: Cambridge University Press

Ferguson, N. (2012) The Great Degeneration: how institutions decay and economies die, London: Allen Lane

Florida, R. (2002) The Rise of the Creative Class: how it's transforming work, leisure, community and everyday life, New York: Basic Books

Florida, R. (2007) The Flight of the Creative Class: the new global competition for talent, New York: Harper Collins

Hayward, J. (undated) Unpublished paper, University of Otago

James, C. (2012) 'Making big decisions for the future', paper presented at the Treasury/Victoria University of Wellington Affording Our Future conference, December
King, C.S., K.M. Feltey and B.O. Susel (1998) 'The question of participation: toward authentic public participation in public administration', Public Administration Review, 58 (4), pp.374-93

Maitlis, S. and H. Ozcelik (2004) 'Toxic decision processes: a study of emotion and organisational decision-making', Organisation Science, 15 (4), pp.375-93

McRae, H. (2011) 'One for the masters of the universe', Independent, 10 October

Nemoti, S. (2011) 'New method to intensify democracy', Asahi Shimbun, 5 June

OECD (2010) Making Reform Happen: lessons from OECD countries, Paris: OECD

Roberts, N. (1997) 'Public deliberation: an alternative approach to crafting policy and setting direction', Public Administration Review, 57 (2), pp.124-32

Tanzi, V. (2005) 'The economic role of the state in the 21st century', Cato Journal, 25 (3), pp.167-38

Tanzi, V. (2011) Government Versus Markets, London: Cambridge University Press

Van den Hove, S. (2006) 'Between consensus and compromise: acknowledging the negotiation dimension in participatory approaches', Land Use Policy, 23 (1), pp.10-17

Vander Ploeg, C.G. (2003) 'Constituent assemblies as vehicles for change', in G. Gibson (ed.), Fixing Canadian Democracy, Vancouver: Fraser Institute

Warren, M.E., and H. Pearse (eds) (2008) Designing Deliberative Democracy: the British Columbia Citizens' Assembly, Cambridge: Cambridge University Press

Zurita, L. (2006) 'Consensus conference method in environmental issues: relevance and strengths', Land Use Policy, 23 (1), pp.18-25 